\title{
Hematite, Biotite and Cinnabar on the Face of the Turin Shroud: Microscopy and SEM-EDX Analysis
}

\author{
Gérard Lucotte ${ }^{1 *}$, Thierry Derouin ${ }^{2}$, Thierry Thomasset ${ }^{3}$ \\ ${ }^{1}$ Institute of Molecular Anthropology, Paris, France \\ ${ }^{2}$ Department of Phanerogamy, Natural History Museum of Paris, Paris, France \\ ${ }^{3}$ Laboratory of Physico-Chemical Analysis, UST of Compiègne, Compiègne, France \\ Email: *lucotte@hotmail.com
}

How to cite this paper: Lucotte, G., Derouin, T. and Thomasset, T. (2016) Hematite, Biotite and Cinnabar on the Face of the Turin Shroud: Microscopy and SEM-EDX Analysis. Open Journal of Applied Sciences, 6, 601-625.

http://dx.doi.org/10.4236/ojapps.2016.69059

Received: June 21, 2016

Accepted: September 13, 2016

Published: September 16, 2016

Copyright $\odot 2016$ by authors and Scientific Research Publishing Inc. This work is licensed under the Creative Commons Attribution International License (CC BY 4.0).

http://creativecommons.org/licenses/by/4.0/

\begin{abstract}
The Turin Shroud, recently accessible for hands-on scientific research, is now extensively investigated. Its pinkish red blood stains that seem anomalous ones are studied by modern techniques (notably by resolute optical microscopy and scanning electron microscopy coupled with energy dispersive X-ray). Exploration by these techniques of a blood stain located on the face permits us to discover some red-colour particles (hematite, biotite and cinnabar) of exogenous material in this stain. We finally characterize these red-colour particles and try to explain their presences in the blood stain. Globally, all these red-colour particles cannot explain all of the reddish appearance of the area under study.
\end{abstract}

\section{Keywords}

Turin Shroud, Blood Stains, Face Area, Hematite, Biotite, Cinnabar, Optical Microscopy, Scanning Electron Microscopy, Energy Dispersive X-Ray

\section{Introduction}

The Turin Shroud (TS), the most important Christ's relic, is a well known object in which a body image is imprinted [1]. This body image is not yet explained by modern science. The frontal image bears apparent blood stains in the areas of the Head (Face and Hairs), Side, Hands and Feet.

The specific nature of these blood stains must be explained in a scientific way, because of the considerable importance of these structures for the religious conscience. There were two alternative explanations that were given in the past to give an account of the red colour of the "blood stains": the first explanation was given by Heller and Adler [2] [3]. Alan Adler made numerous efforts to explain red blood like a novel 
complex formed as a result of crucifixion trauma; he proposed that it was a mixture between Bilirubin and an exotic complex of oxidised met-hemoglobin (that he called "parahemic") that was responsible for the observed red-brown colour of the TS blood stains.

At that time (and at the opposite), Walter McCrone [4], on the basis of polarized light microscopy studies of the TS red particles, established that this red-brown colour was mainly due to aggregates of crystalline particles of hematite (an iron-oxide mineral) and vermilion (a painting constituted of cinnabar mineral).

Recently, Adrie van der Hoeven [5] proposed a new argument hypothesis in continuation to the initial Heller theory: for him, TS pinkish red blood stains contained acid-heme madder lake, of which the heme derived from cold acid post-mortem blood (madder had been applied to the TS at manufacture).

Last year I have published [6] a SEM (Scanning Electron Microscopy)-EDX (Energy Dispersive X-ray) study on red blood cells (RBC) on a sticky-tape triangle taken in a little blood area located in some part of the TS Face. Only twenty-five corpuscules (or corpuscule groups) that are red blood cells according to morphological and chemical criteria were found (moreover, their colour is generally white); so, that number is too low to explain the observed general reddish colour of the triangle. In the present study we search for evidence of hematite (Appendix 1, Figure S1), biotite (Appendix 2, Figure S2) and cinnabar particles on the triangle surface.

\section{Material and Methods}

The material [7] is a small ( $1.36 \mathrm{~mm}$ height, $614 \mu \mathrm{m}$ wide) sticky-tape triangle at the surface of which portions of textile fibres [8], pollen grains and spores [9] and red blood cells were deposited. As declared by Riggi di Numana, who had taken the sample, this sticky-tape triangle is some part of a larger piece he placed directly (during the 1978 official sampling) on the TS surface, at one "blood area" of the Face.

More than 2500 particles, greater than $1 \mu \mathrm{m}=\mu$, can be observed at the surface of the triangle; all of them were studied by optical microscopy, SEM and EDX analysis. For practical reasons, the surface of the triangle was subdivided into 19 sub-samples areas (A to S), adjacently located on the triangle surface and containing almost all the particles observed.

Particles of the samples were observed, without any preparation, on the adherent part of the surface of the triangle. Detected particles of interest were observed by optical microscopy (using a photomicroscope Zeiss, model III 1972, and its petrographic version) and analysed by SEM and EDX. Two SEM apparatus were used: 1/A Philips XL30 instrument (environmental version); GSE (Gaseous Secondary Electrons) and BSE (Back Scattered Electrons) procedures are used, the last one to detect heavy elements. Elemental analysis for each particle were realised by EDX, this SEM microscope being equipped with a Bruker AXS-EDX (the system analysis is PGT: Spirit model, of Princeton Gamma Technology). 2/A FEI model Quanta 250 f FEG (probe Bruker model X-flash 6/30); both LFD (Large Field Detector) and CBS (Circular Back Scattering) procedures were used. 
For each hematite and biotite particles, optical microscopy (colour photography) precedes SEM observations (with the first SEM apparatus, the second, or both); EDXanalysis were always realized, for all of these particles.

\section{Results}

Figure 1 shows optical microphotographs of particles $(18,111,114,115,117,118,122,123$, $126,134,138,139$ and 141) located on the top of the $\mathrm{L}$ area of the triangle (at the limit between the $\mathrm{K}$ and $\mathrm{L}$ areas), where there is a maximal density of red particles. In these "kaleidoscopic" views, some particles: 139, 134 (at the top), 126, 18 and 111, appear clearly

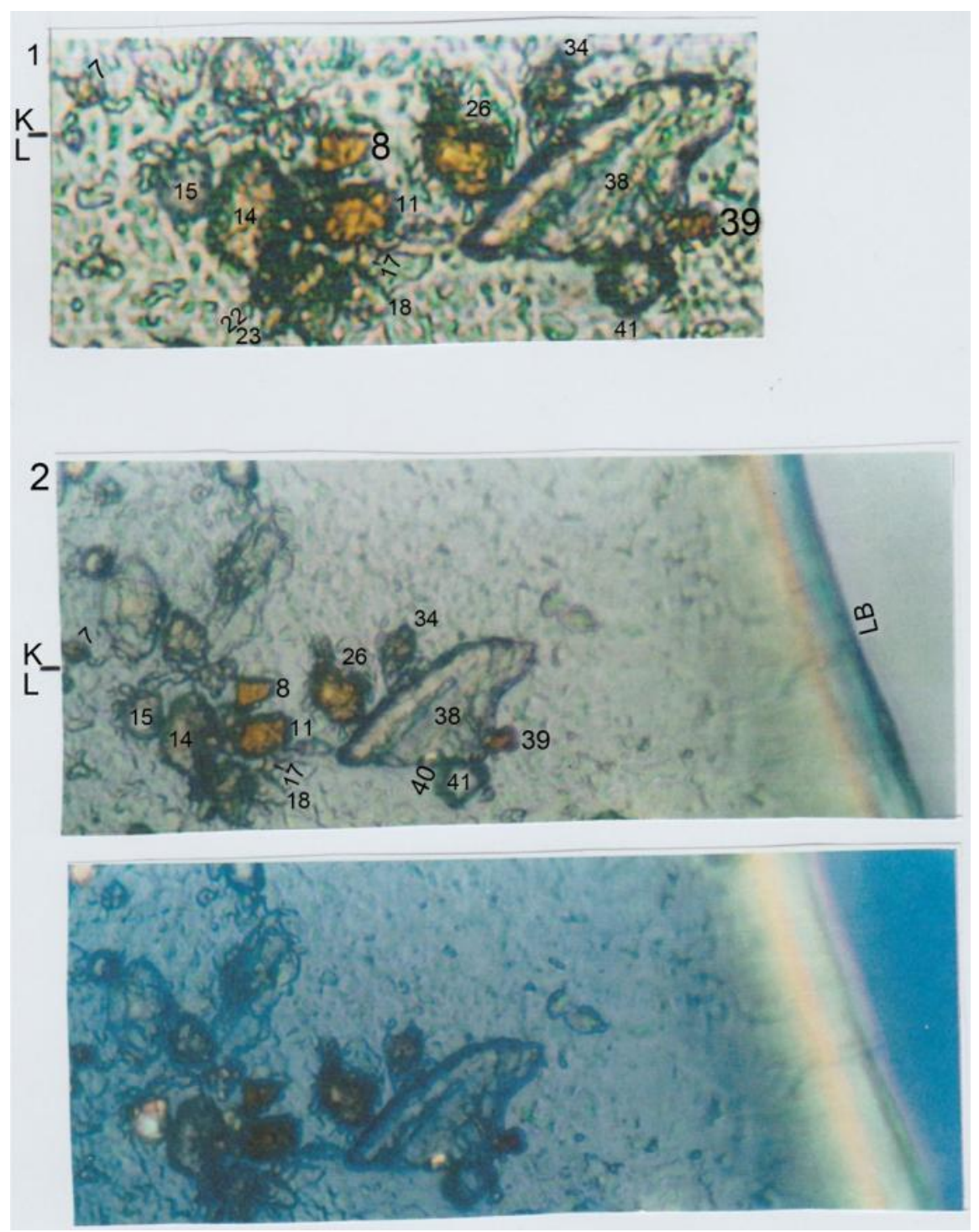

Figure 1. Optical microscopy (inverted) views of red particles located at the limit between areas $\mathrm{K}$ and $\mathrm{L}$ of the triangle. Above 1): coloured view $(2 \times)$ of the particles (particles 139 and 18; particles $111,114,115,117,118,126,134,138$ and 141). Below: 2$)$ : optical microscopy view (1200×), in polarized light, at two different angles (particles 18, 111, 114, 115, 117, L18, 126, 134, 138, 139, 140 and 141); LB: left border of the triangle. 
as red in colour (Table 1). In polarized light, only 140 (a calcium carbonate) and 115 (a calcite) bi refract. The photography also shows the yellow particle 17, which is a goethite.

\subsection{Hematite}

The particle 139 (Figure 2), a little plaque $(6.5 \times 3.7 \mu)$ of red colour, is a typical hematite (see Appendix 1, Figure S1): the mineral part of her spectrum corresponds to that of a hematite, with a very elevated iron content (in relative value, as measured without $\mathrm{C}$ and $\mathrm{O}$ ) of $43 \%$. Enlarged views of the 139 left upper part (Figure 3 ) show numerous iron inclusions, that is the most characteristic property of the hematite mineral.

There is only one convincing evidence of another hematite particle on the surface of the triangle: in the $\mathrm{O}$ area (Figure 4), the 07 particle (triangular in form: $6 \times 3.7 \mu$ ) had a mineral part of her spectrum corresponding to that of a hematite, an elevated iron content of $60.7 \%$, and characteristic iron inclusions in its uncovered part (Figure 5). Almost all of the 07 surface is covered by calcium carbonate deposit that masks partially its initial red colour (Figure 4, lower photography).

\subsection{Biotite}

The particle 18 (Figure 6), a little plaque of red colour, is a typical biotite (see Appendix 2, Figure S2): the mineral part of its spectrum corresponds to that of a biotite, without iron inclusions, and a very elevated iron content of $50.4 \%$.

There are six evidences of other biotite particles on the surface of the triangle (Table 2): particles g34-34' (Figure 7) located in the G area of the triangle, particle j56 in the J area (Figure 8), particles k70 (Figure 9) and k80 (Figure 10) in the K area, particle 168 (Figure 11) in the $\mathrm{L}$ area, and particle p23 (Figure 12) in the $\mathrm{P}$ area.

Table 1. L observed particles (Figure 1) characteristics.

\begin{tabular}{cccc}
\hline Particles & Red in colour & Minerals & Birefraction \\
\hline 18 & + & biotite & $\begin{array}{c}\text { slightly; but the birefringency is masked by } \\
\text { sombre proper-tint of the mineral }\end{array}$ \\
111 & + & phosphorite clay, iron-rich & no \\
114 & lightly & a brick fragment & no \\
115 & & calcite & + \\
117 & yellow-red & K-aluminosilicate & no \\
118 & & a silica & no \\
126 & + & K-aluminosilicate & no \\
134 & at the top & a washing powder & no \\
138 & & a wax & no \\
139 & + & hematite & no \\
140 & & calcium carbonate & + \\
141 & & quartz & no
\end{tabular}




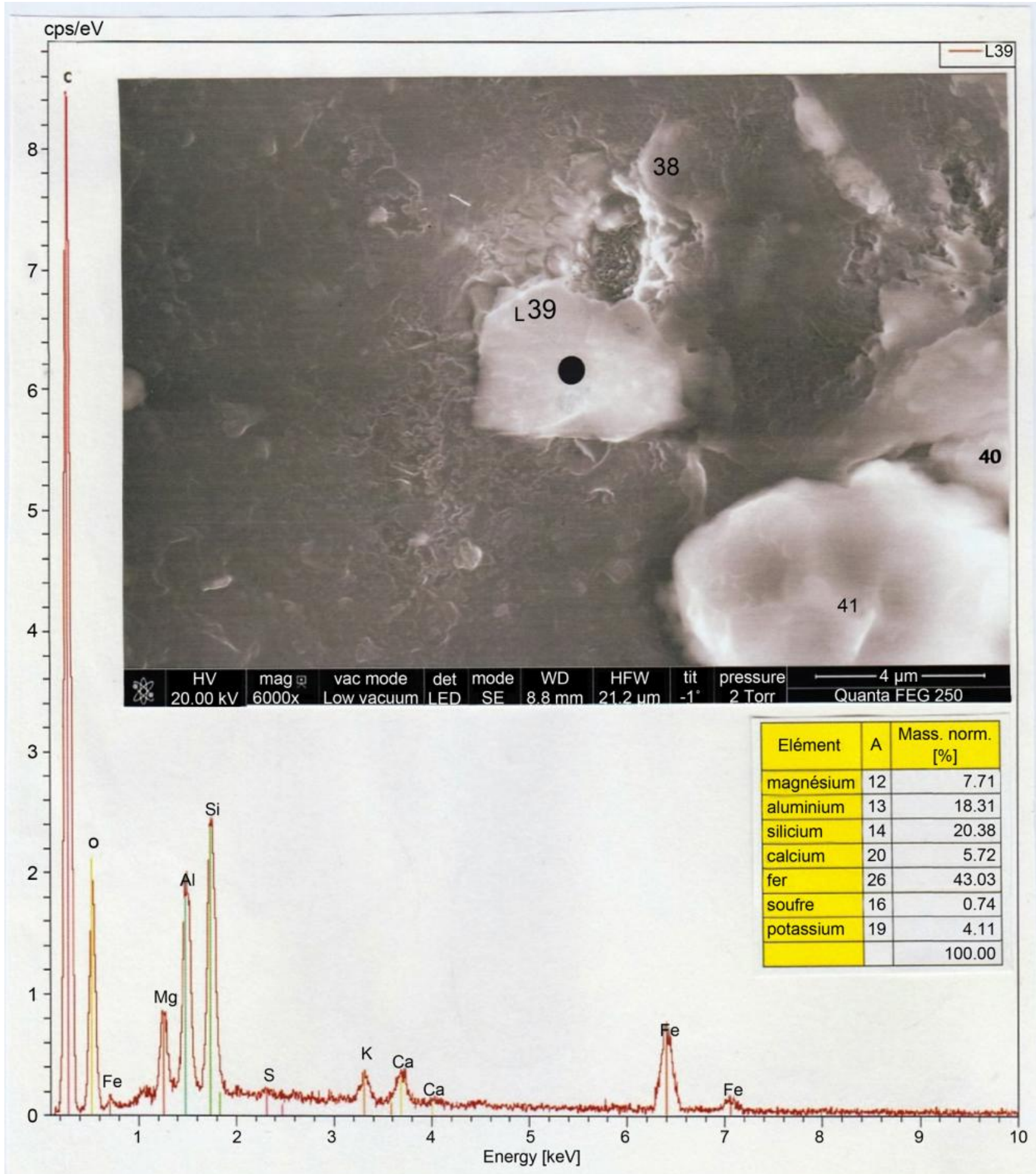

Figure 2. Above: SEM photography $(6000 \times)$ of the hematite 139 particle; adjacent particles: 138,140 and 141 . Below: 139 spectrum taken at the black point indicated (the table indicates iron percentage).

Table 2 summarizes the main characteristics of the seven biotites detected. Their forms are like plaques (j56, k70, k80, 18, p23), or more voluminous particles with rounded extremities (g34-34' and 168). Their maximal length evolve between 4 and $9 \mu$, 

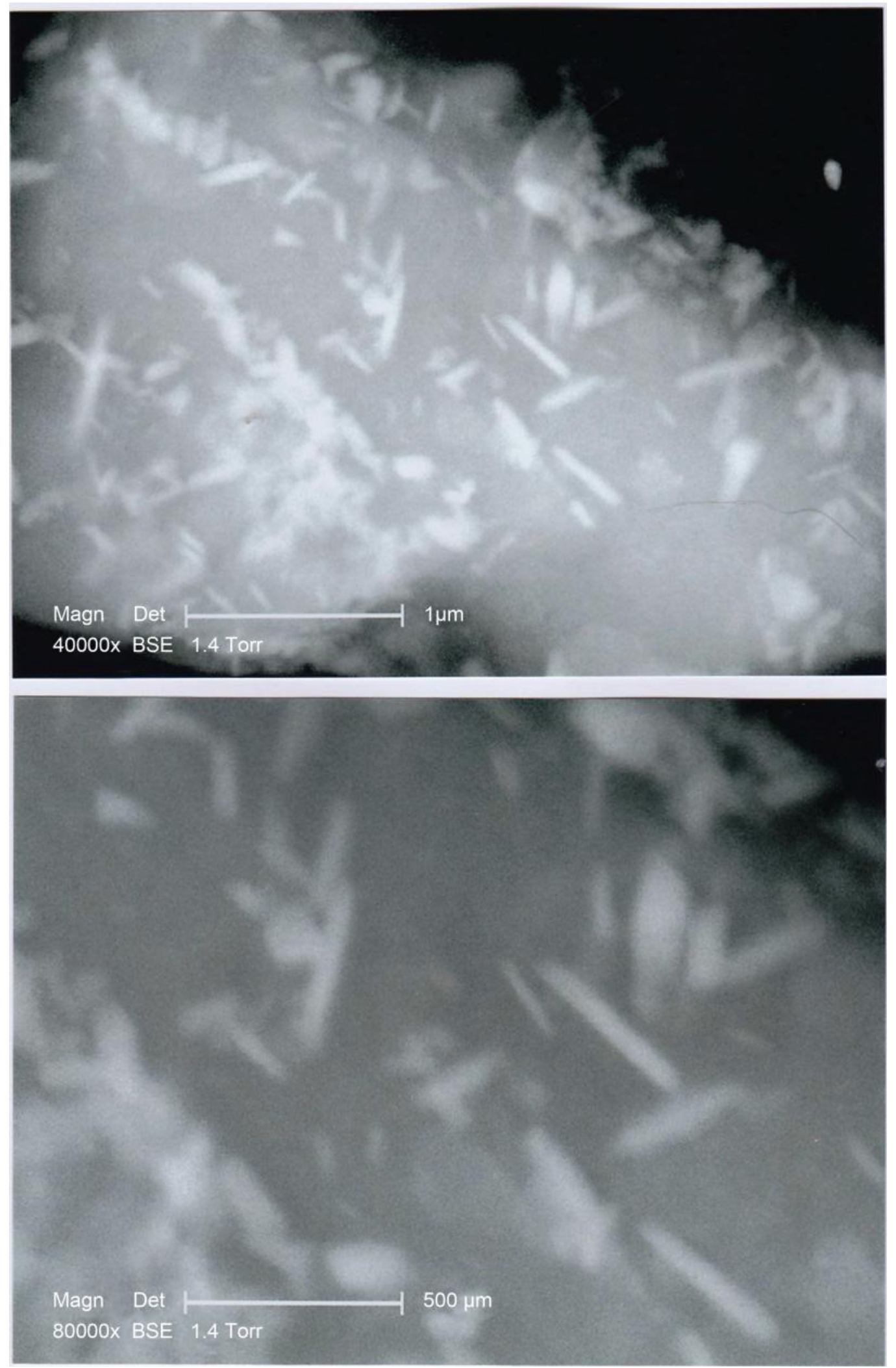

Figure 3. SEM photographs (above: 40,000×; below: 80,000×) of the 139 particle in BSE, of one portion (left upper part) of the particle showing iron inclusions. 


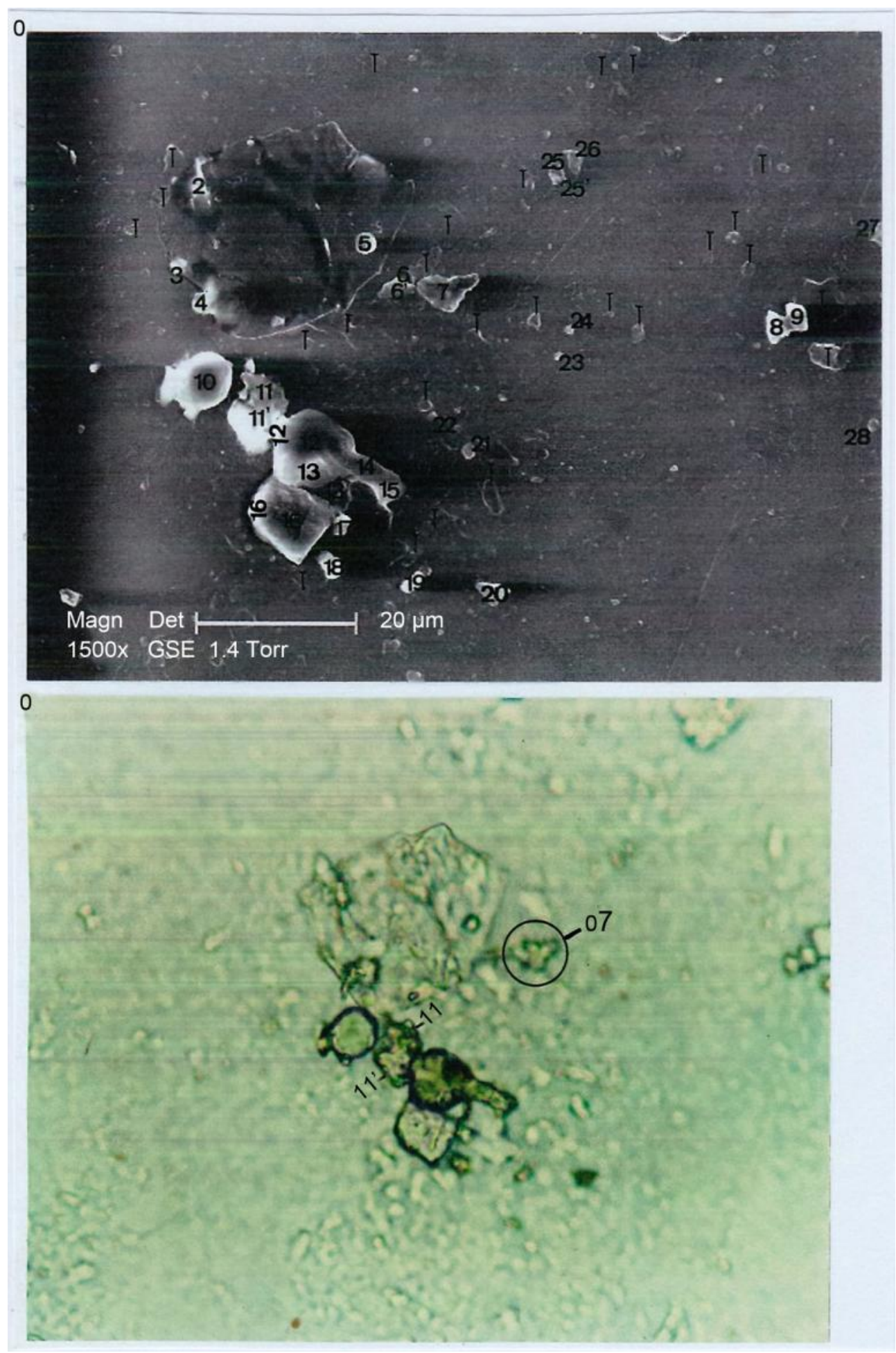

Figure 4. Above: SEM (1500×) photography of the O area of the triangle. Below: an optical microscopy view of the same area $(1200 \times)$; particle o7 is encircled.

the greatest one being 168 (with a length of about $13 \mu$ ). Their colours are red, j56 being orange, k80 pale red, and g34-34' red-brown. All have spectrums conform to that of 


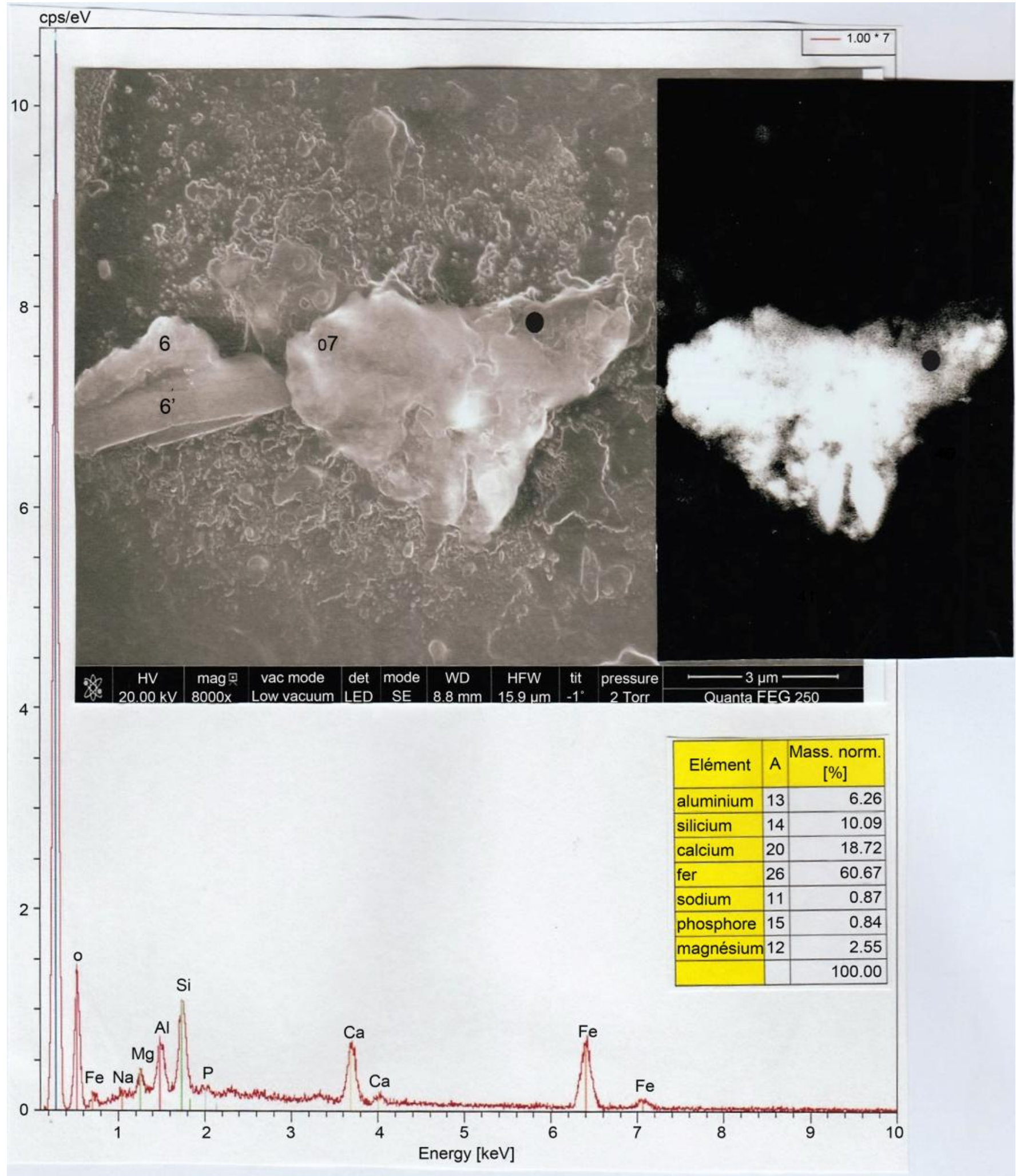

Figure 5. Above: SEM photographs $(8000 \times)$ of the hematite o7 particle (left photography, in LFD; right photography, in CBS); adjacent particles: 06 (sulphur), o6' (talc). Below: o7 spectrum, taken at the black points indicated on the photographs (the table indicates iron percentage). 


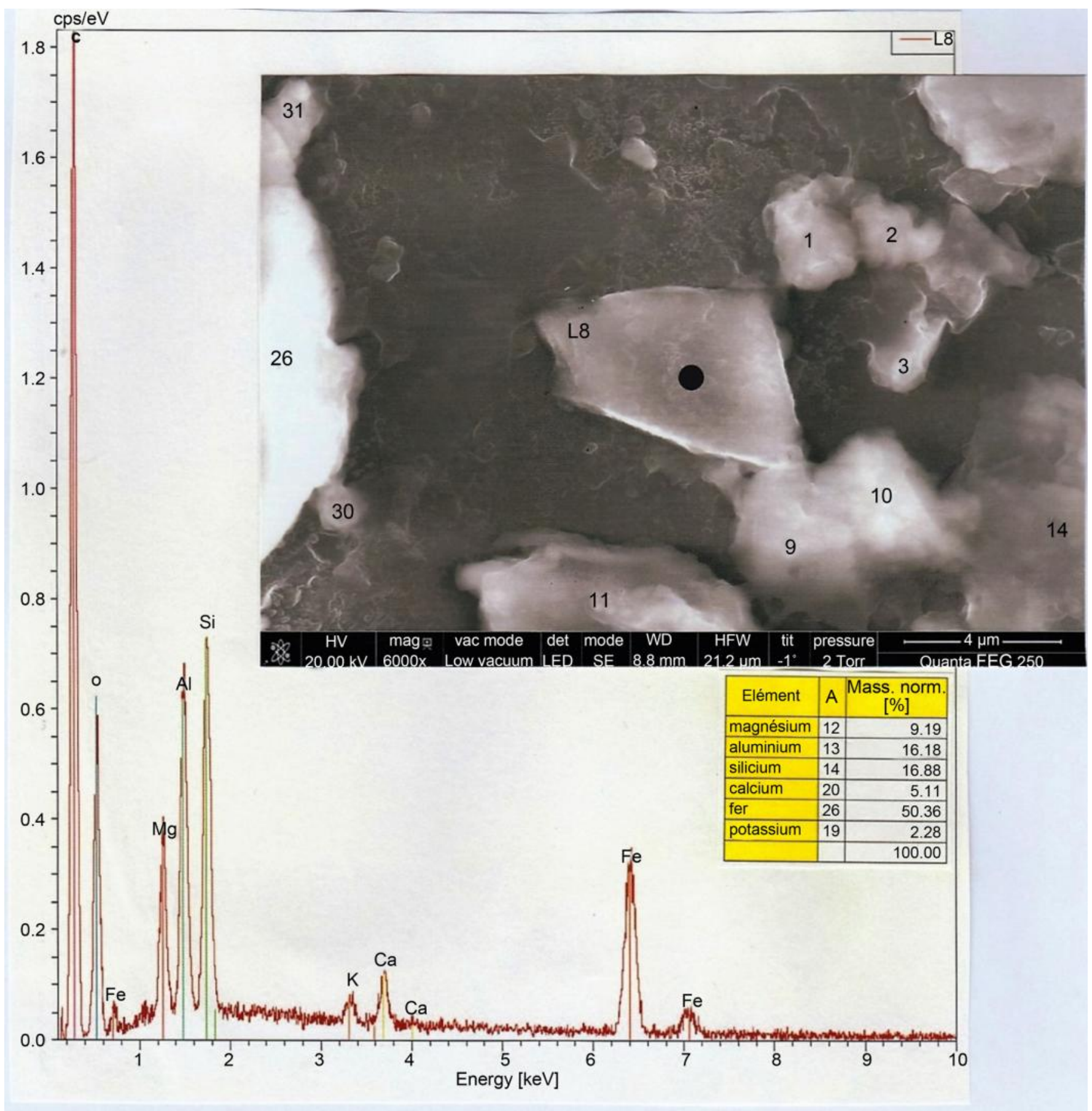

Figure 6. Above: SEM photography $(6000 \times)$ of the biotite 18 particle. Adjacent particles: 11 (magnesite), 12 (calcite), 13 (calcite), 19 (calcite), 110 (calcium carbonate), 111, 130 (calcites), 126 and 131 (calcites). Below: 18 spectrum taken at the black point indicated (the table indicates iron percentage).

biotite. All the biotite particles have no iron inclusions. Their iron percentages evolve between $24.4 \%$ (g34-34') and 50.4\% (18, the biotite type). The iron percentages of both $\mathrm{j} 56$ and $\mathrm{k} 80$ are less than $10 \%$ but there is an elevated peak of oxygen in their spectrums (iron oxide) that explains their red (or quasi-red) colour observed. 
Table 2. Main characteristics of the seven biotite particles observed.

\begin{tabular}{|c|c|c|c|c|c|}
\hline \multicolumn{2}{|c|}{ NumbersNomenclature } & \multirow{2}{*}{$\begin{array}{c}\text { Aspect } \\
\begin{array}{c}\text { Volume, with rounded } \\
\text { extremities }\end{array}\end{array}$} & \multirow{2}{*}{$\begin{array}{c}\text { Dimensions }(\text { in } \mu) \\
9 \times 3.5\end{array}$} & \multirow{2}{*}{$\begin{array}{l}\text { Colour } \\
\text { brown }\end{array}$} & \multirow{2}{*}{$\begin{array}{c}\text { Iron \% } \\
24.4\end{array}$} \\
\hline B1 & g34-34' & & & & \\
\hline B2 & j56 & plaque & $4 \times 5$ & orange & $\begin{array}{l}<10 \% \text {, but there is an } \\
\text { important peak of oxygen }\end{array}$ \\
\hline B3 & k70 & Elongated plaque & $8.5 \times 4$ & red & 44.6 \\
\hline B4 & $\mathrm{k} 80$ & plaque & $6 \times 4$ & red pale & $\begin{array}{l}<10 \% \text {, but there is an } \\
\text { important peak of oxygen }\end{array}$ \\
\hline B5 & 18 (type) & plaque & $5.5 \times 4$ & red & 50.4 \\
\hline B6 & 168 & $\begin{array}{l}\text { Volume, with rounded } \\
\text { extremities }\end{array}$ & $13 \times 6.5$ & red & 38.7 \\
\hline B7 & p23 & plaque & $4 \times 3.5$ & red & 32.7 \\
\hline
\end{tabular}

\subsection{Cinnabar}

We do not observe any cinnabar particle in the $\mathrm{L}$ area. We only found one cinnabar particle on the surface of the triangle: the particle k56 (Figure 13), that is located in the lower part of the $\mathrm{k}$ area; optically, it is of pale red (yellow) colour.

\subsection{Others}

Four particles in the $\mathrm{L}$ area $(126,117,111,134)$, other than the hematite 139 and the biotite 18, are more or less red in colour (see Figure 1). Both 126 and 117 are K-aluminosilicates; their reddish colour is due to different amounts of iron oxide. Both of their spectrums show an equality in height of their predominant peaks of silicium and aluminium. They are anthropic material (intervening in cements). We have found two other particles of this sort (158 and 164) in the $\mathrm{L}$ area, and at least seventeen others at various parts on the surface of the triangle. Their shapes and sizes vary, as well as their reddish colour (depending on their iron contents).

The 111 particle is a phosphorite iron-rich clay. Some particles of this sort were found in different parts of the triangle surface.

The 134 particle is a phosphorite without iron (a washing powder), calcium being more abundant at its top (that explains its local reddish colour). Phosphorites and red clays belong to the same class of red dyes that were deposited on the TS Face at the level of blood stains [4].

\section{Discussion}

We have found a total number of two hematite particles (129 and o7), of seven biotite particles (g34-34', j56, k70, k80, 18, 168 and p23), and of one cinnabar particle (k56) on the triangle. Figure 14 shows their distributions among the different parts of the triangle surface; in any case they can explain all of the reddish colour observed in optical microscopy for some important portions of this surface. 


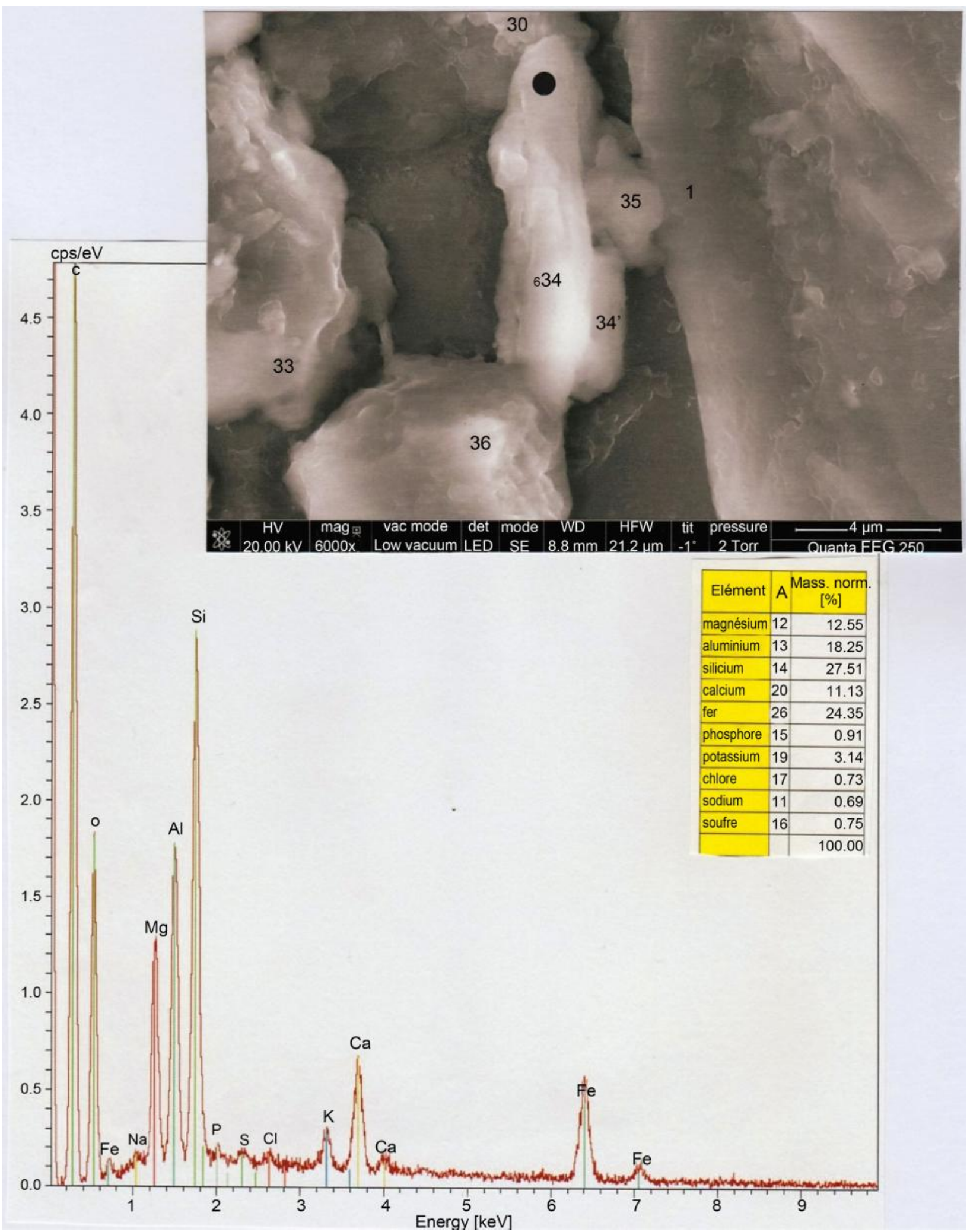

Figure 7. The g34 particle. Above: SEM (6000×) photography of g34 (and g34') particles. Adjacent particles: g1 (a peridot), g35 (calcite), g30 (a clay), g36 (a silica) and g33 (a clay). Below: the g34 spectrum (g34' spectrum is identical) at the black point indicated (table shows elemental g34 percentages). 


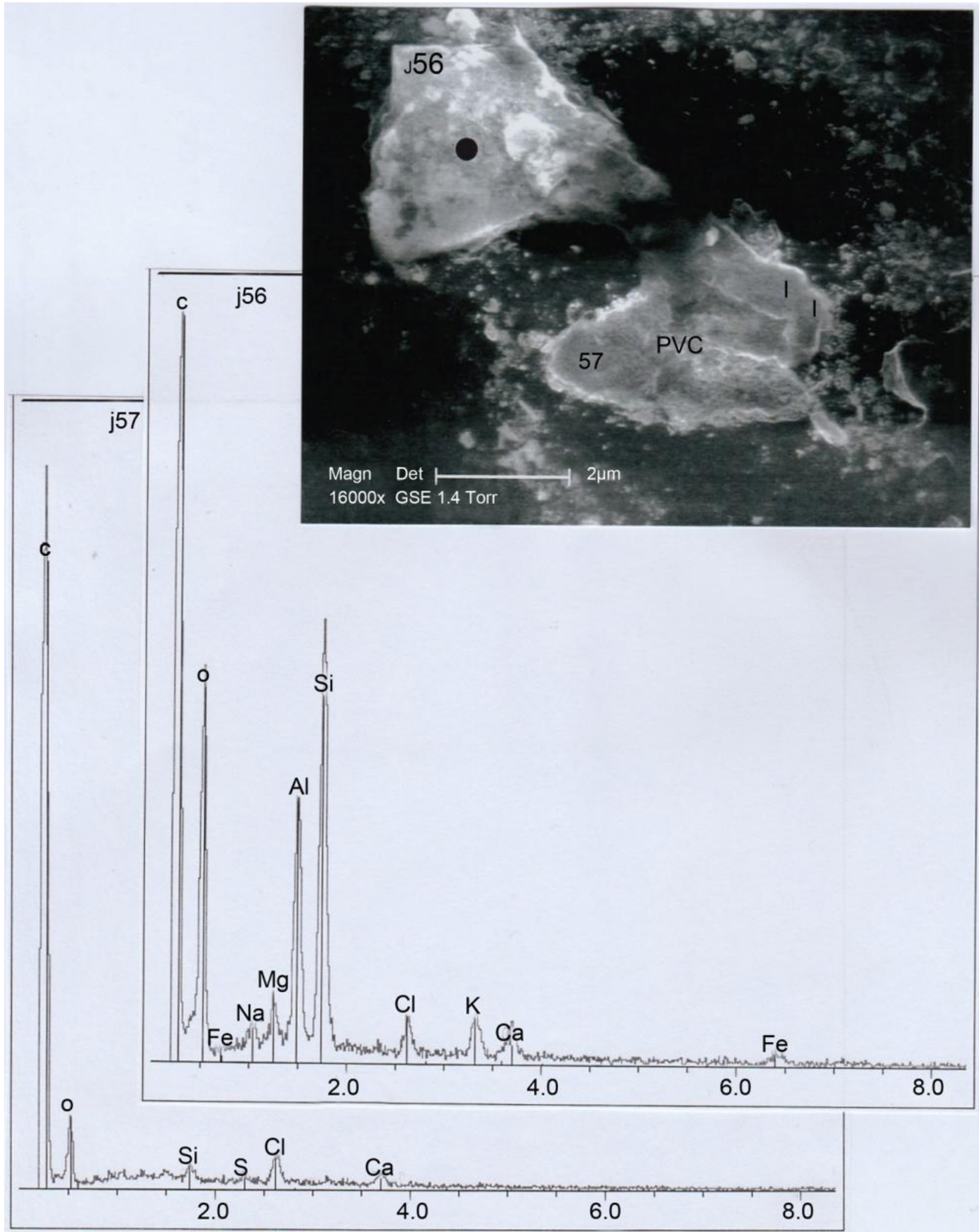

Figure 8. The j56 particle. Above: SEM (16,000×) photography of the j56 particle; adjacent particle g57: a plastic PVC (Polyvinyl Chloride) particle (l: lobes). Below: the j56 spectrum at the black point indicated (the below spectrum is that of the j57 particle). 


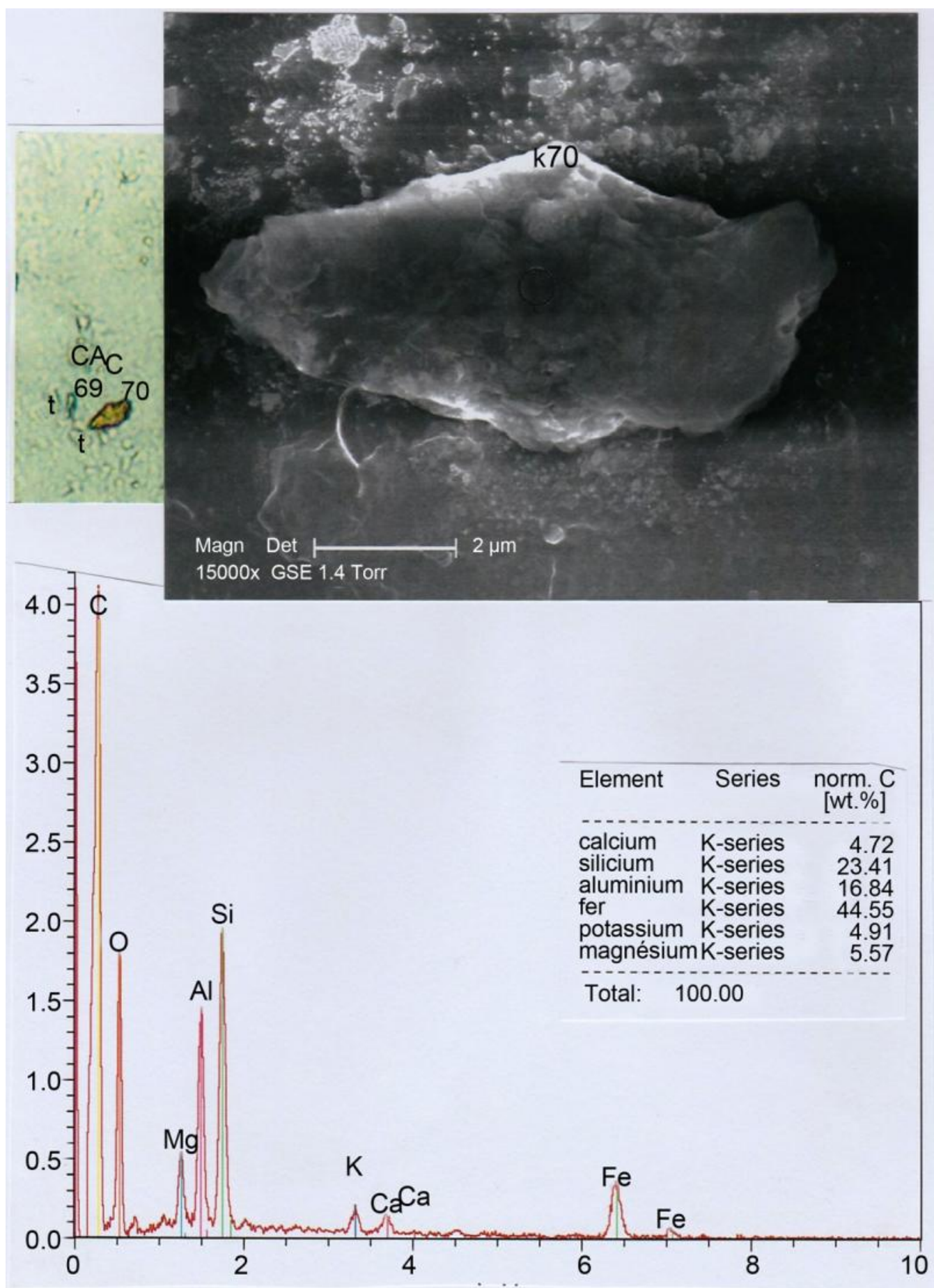

Figure 9. The k70 particle. Above: SEM (15,000×) photography of the k70 particle left corner: an optical microscopy photography $(1000 \times)$ of the k70 (k69: aragonite; CA: calcite; C: calcium carbonate; t: holes). Below: the k70 spectrum, at the point indicated as a black circle (table shows elemental k70 percentages).

Particle 139 (see Figure 2) is a typical hematite mineral (by mineral composition, elevated iron content and iron inclusions). There are numerous evidences that hematite powders were used as red pigments, since prehistory and beyond [10]. 


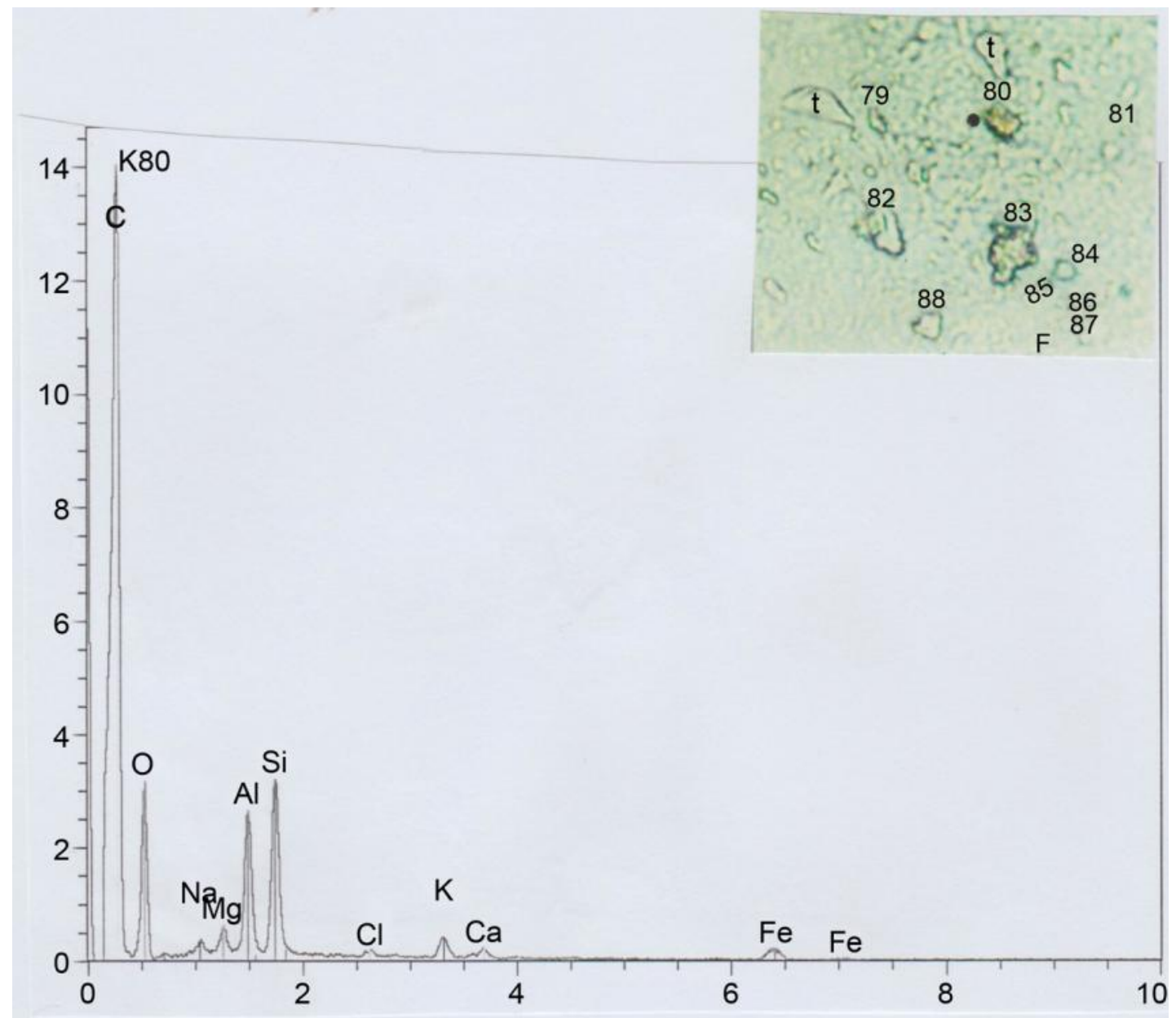

Figure 10. The k80 particle. Above (upper right corner): an optical microscopy photography $(1000 \times)$ showing the $\mathrm{k} 80$ particle near the black point. Neighbouring particles: $\mathrm{k} 79$ (talc), k81 (calcium carbonate), k82 (clay, iron-rich), k83 (phosphorite), k84 (gypsum), k85 (calcite), k86 (calcite), k87 (calcite) and k88 (talc). Below: the k80 spectrum.

Hematite particle o7 (see Figure 5) presents the singularity to be quasi-entirely covered by a thin deposit of calcium carbonate (that masks the red colour of the particle). Spectrum resolution cannot permit to precise the exact mineral matter (calcite, other forms of calcium carbonate...) of this deposit of calcareous material. The fine-grained white matter conserved at the surface of this hematite particle could be possibly the result of some grinding or scraping process (but it is difficult to determine if it was followed by some sifting process).

As established on archaeological pigments [11], there is a growing evidence that hematite can be obtained by heating goethite (see Appendix 3, Figure S3) up to elevated temperatures $\left(300^{\circ} \mathrm{C}-350^{\circ} \mathrm{C}\right)$, depending on the level of impurities present in the initial material and microstructural features (such as grain sizes and shapes). The corresponding colour change from yellow (goethite) to red (hematite) is associated to the loss of some water molecules [12]; such temperature-treatment is able to induce the goethite transformation, according to the following reaction: $2 \mathrm{FeOOH} \Rightarrow \mathrm{Fe}_{2} \mathrm{O}_{3}+\mathrm{H}_{2} \mathrm{O}$. 


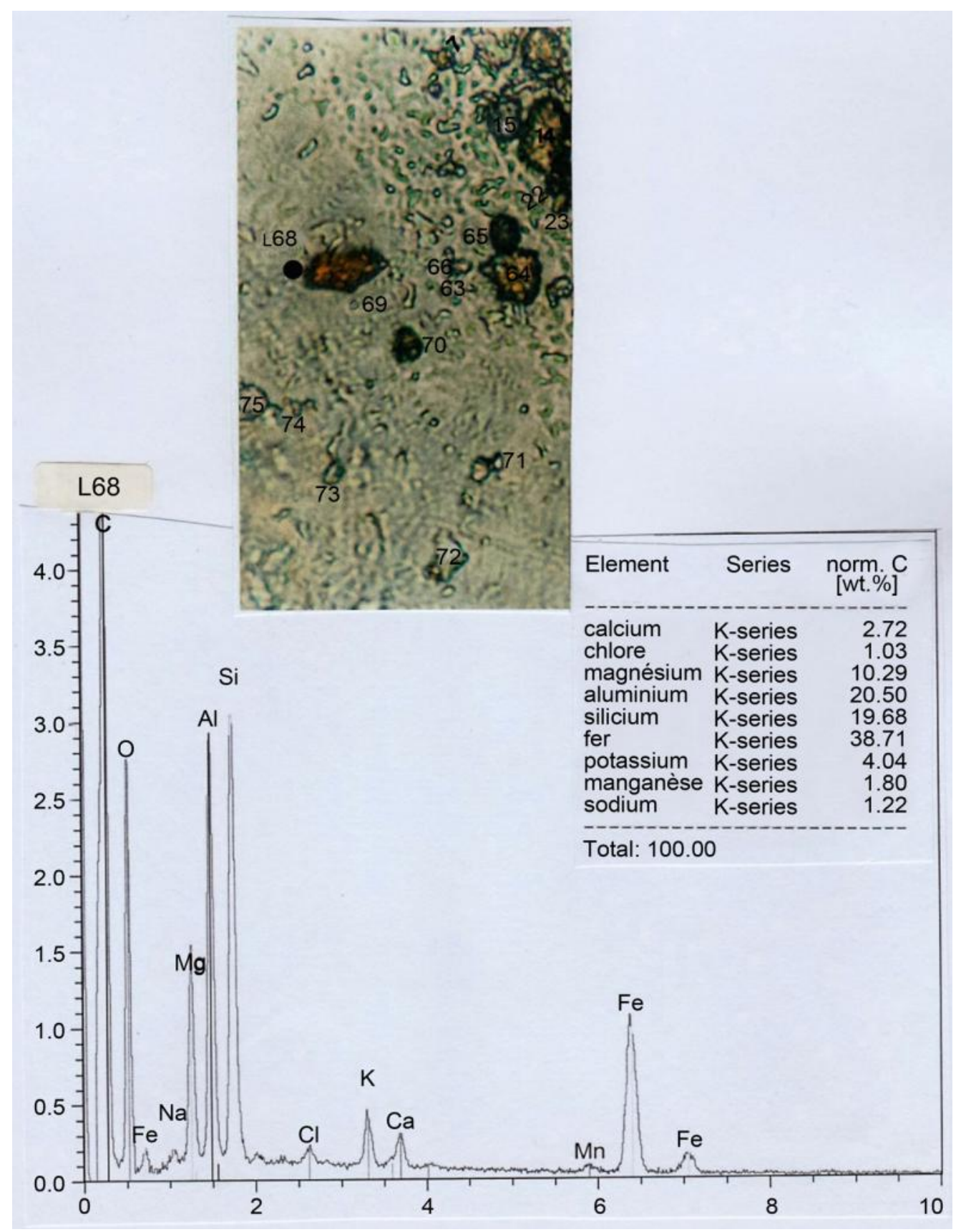

Figure 11. The 168 particle. Above: optical microscopy photography $(1000 \times)$ of the 168 particle, near the black point. Adjacent particles: 169 (calcite), 170 (a clay), 163 (gypsum), 166 (calcium carbonate), 165 (calcium carbonate), 164 (K-aluminosilicate, with iron), 165 (calcium carbonate), 122 (calcite) and 123 (an organic particle). Above: the 168 spectrum (table shows elemental 168 percentages).

This treatment causes also a complete recrystallization and a partial sintering of the hematite grains, with a simultaneous reduction of structural and chemical defects [13].

We can see this process at work on the TS sample: in the $\mathrm{O}$ area of the triangle (see Figure 4) the particle o11-11', located in the vicinity of o7, is also covered by some deposits of calcite-calcium carbonate material (Figure 13); the o11-11' morphology, studied 


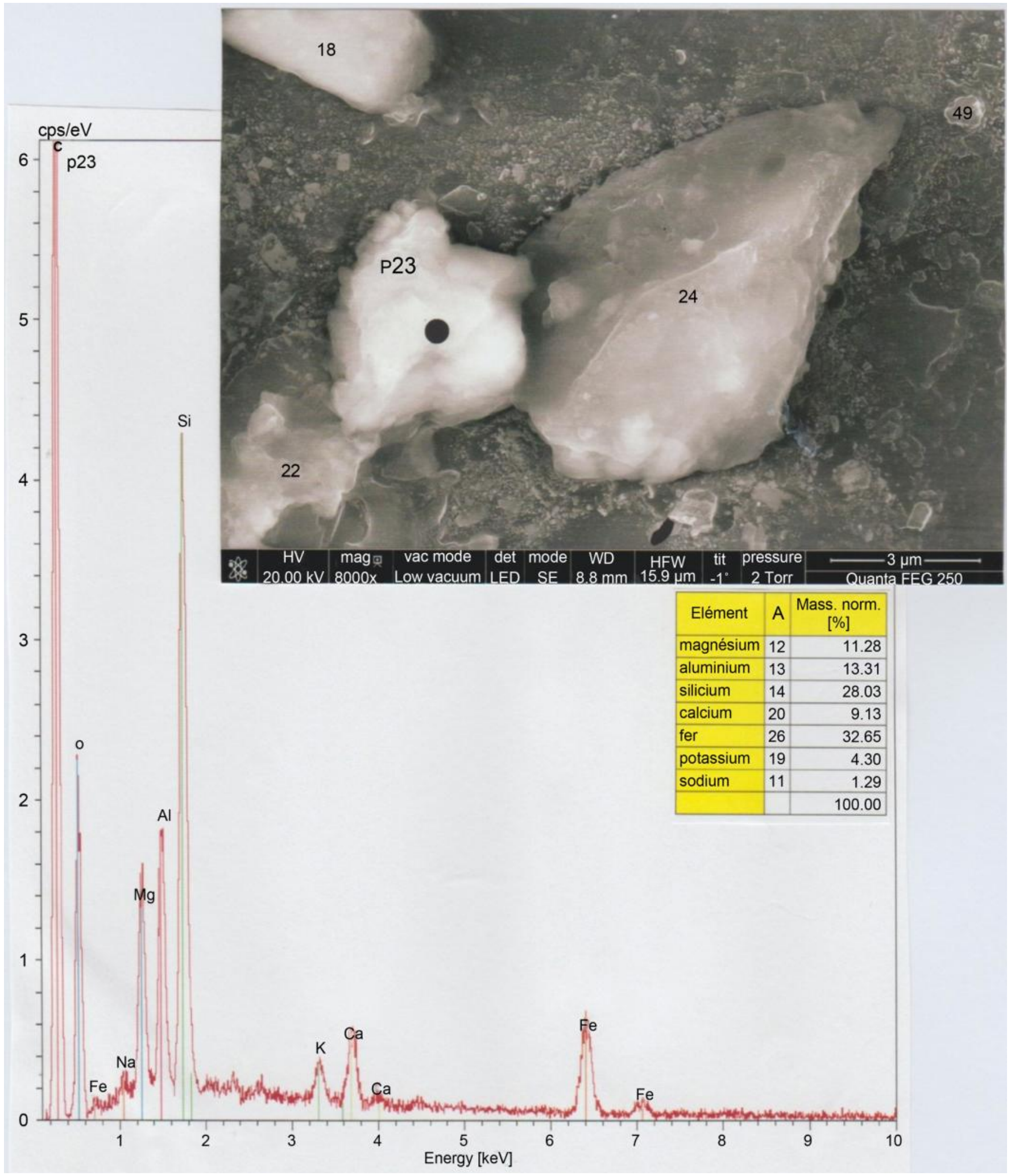

Figure 12. The p23 particle. Above: SEM (8000×) photography of the p23 particle. Adjacent particles: p22 (talc), p24 (a jay), p18 (calcite), p19 (iron-oxide micro-particle) and p49 (calcite). Below: the p23 spectrum, at the black point indicated (table shows elemental p23 percentages). 


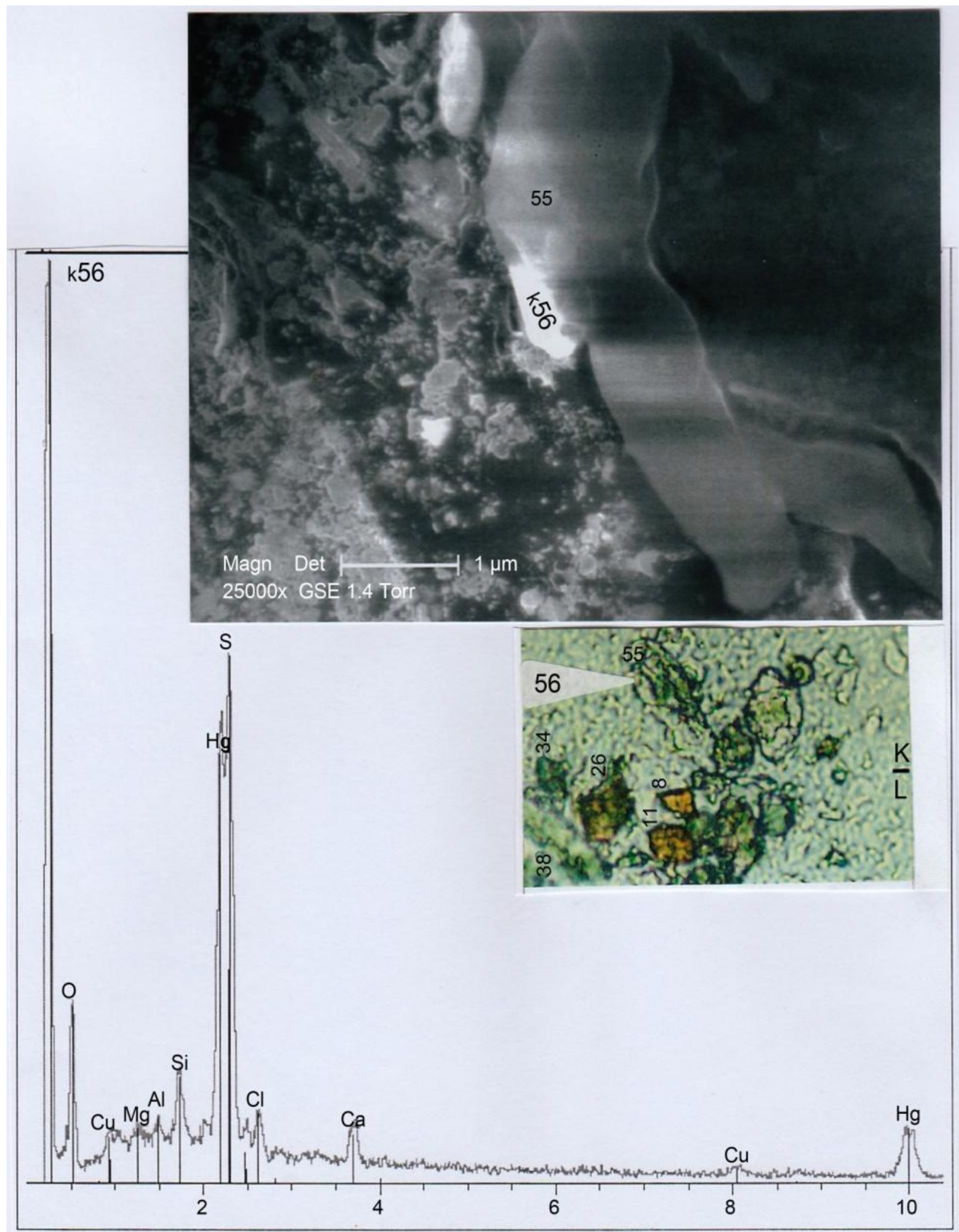

Figure 13. The k56 particle. Above: SEM $(25,000 \times)$ photography of the k56 particle; the adjacent particle p55 is a plastic PVC. Below photography: optical view $(1000 \times)$ of the lower part of the $\mathrm{K}$ area of the triangle showing the $\mathrm{k} 56$ particle and the adjacent k55 (L particle numbers are indicated vertically). Below: the k56 spectrum. 


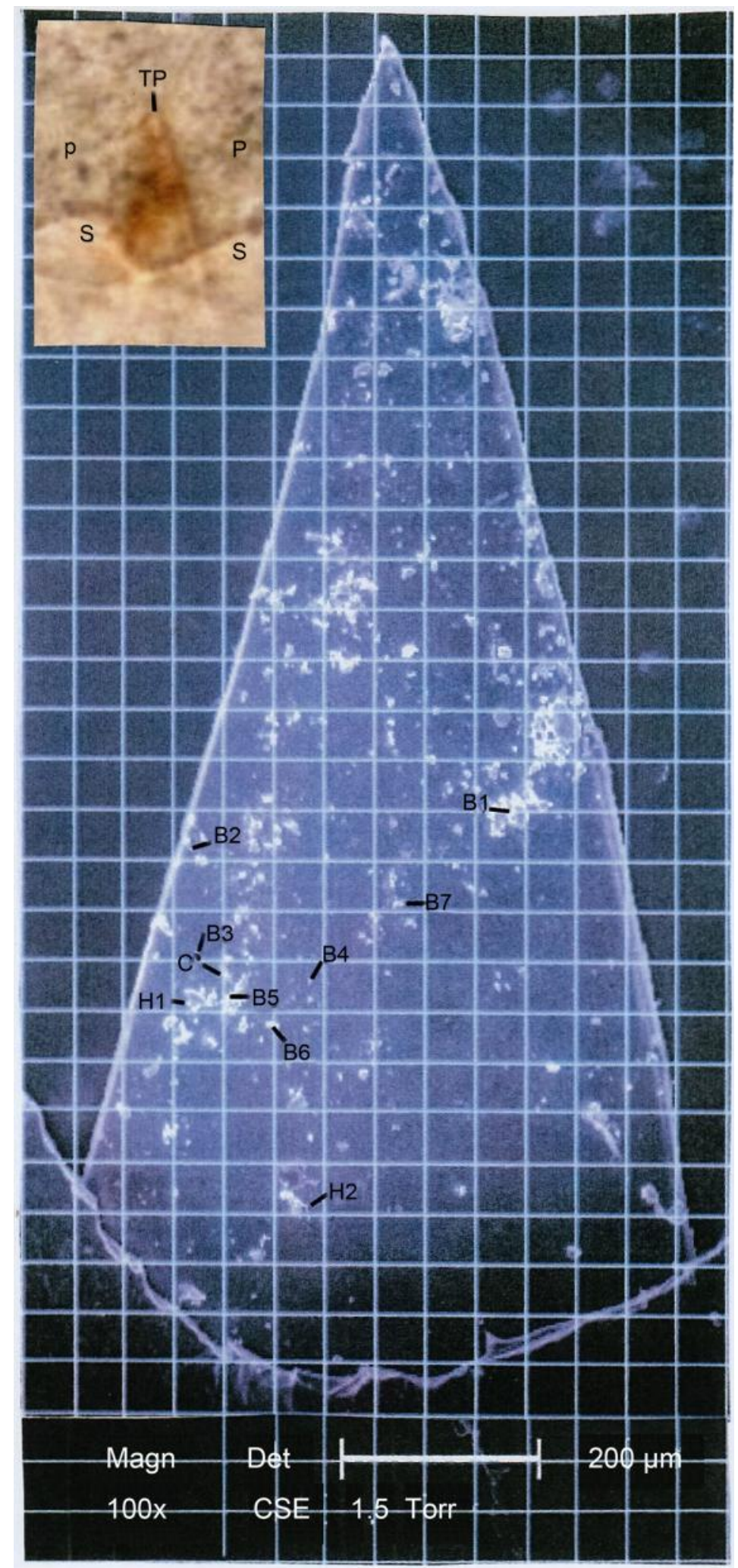

Figure 14. Locations of the particles on the triangle. H: hematies (H1: 139, H2: 07); B: biotites (B1: g34-34', B2: j56, B3: k70, B4: k80, B5: 18, B6: 168, B7: p23); C: cinnabar (k56). Upper left corner: optical photography $(10 \times)$ showing the triangle (S: scotch, P: paper, TP: triangle point). 
in SEM), shows all the characteristics (fracture and pores) of an hot-heated transformed mineral.

As for hematite, there is also evidence that biotic powder can be used as a red pigment (or/and as charge), and that since the prehistoric times [14].

To our knowledge, it is the first time that biotite particles are signalled on the TS. Of the seven biotite particles that we observed, four of them (18, 168, k70 and k80) are concentrated in the same location, in the $\mathrm{L}$ and the lower part of the $\mathrm{K}$ area of the triangle (see Figure 14). Of the seven biotite particles observed (Table 2), five (j56, k70, k80, 18 and p23) are plaques and two (g34-34' and 168) are grains; these two grains are the most voluminous biotite particles. All the biotite particles observed are of marked reddish colour (and they had substantial iron contents). The pale-red and orange colourations of biotite particles $\mathrm{k} 80$ and $\mathrm{j} 56$ are due to their relatively low iron contents; the brown particle g34-34' had an iron content of $24.4 \%$.

Probably all these observed biotite particles came from those of fine powders, pulverised or paint-included, deposited at the Face surface in the "blood stain". Choice of these powders by operators was guided by the intention to obtain a special mica-powder category (from the point of view of a finest powder, intensively red coloured). We suggest that the goal was to revive the red colour of the blood that necessarily stumped with time. Being the heterogeneity (in shapes, iron oxide levels and subtle differences in red-colour intensities) of the biotite particles observed, we can deduce that several sorts of such special mica-powder preparations were used successively.

Cinnabar particle k56 (see Figure 15) is certainly a paint-fragment of vermilion $(\mathrm{HgS})$, a characteristic red coloured artist pigment that was commonly used in the Middle-Age [15]. Figure 16 shows examples of SEM-EDX analysis of vermilion paintfragments particles located on the surface of another Christ relic. It is known that the red colour of vermilion fades with time, which explains the yellow colour of the observed k56 particle.

\section{Conclusions}

Exploring by such a resolutive optical microscopy and by SEM-EDX analysis-a blood stain located on the Face of the TS-we have found in its ten particles of red-yellow colour: two hematite particles, seven biotite particles and one cinnabar particle.

Of the two hematite particles, one of them is covered by a fine layer of calcium carbonate (that indicates its artificial nature). In the vicinity of the first hematite particle, we have observed a peculiar transformed clay particle that permits us to see in action the goethite $\Rightarrow$ hematite thermal transition. The seven biotite particles detected-it is the first time that such a mineral is observed on the TS-show different shapes, iron contents and subtle nuance of red-colour; we concluded that several biotite preparations were used during time to revive the reddish colouration of the blood stain, but it was possible that such particles were contaminations from other stuffs. The cinnabar particle is clearly a paint-fragment of vermilion; because this vermilion particle is unique, and this establishes that the blood spot is, on the whole, not red coloured by such a painted dye. 


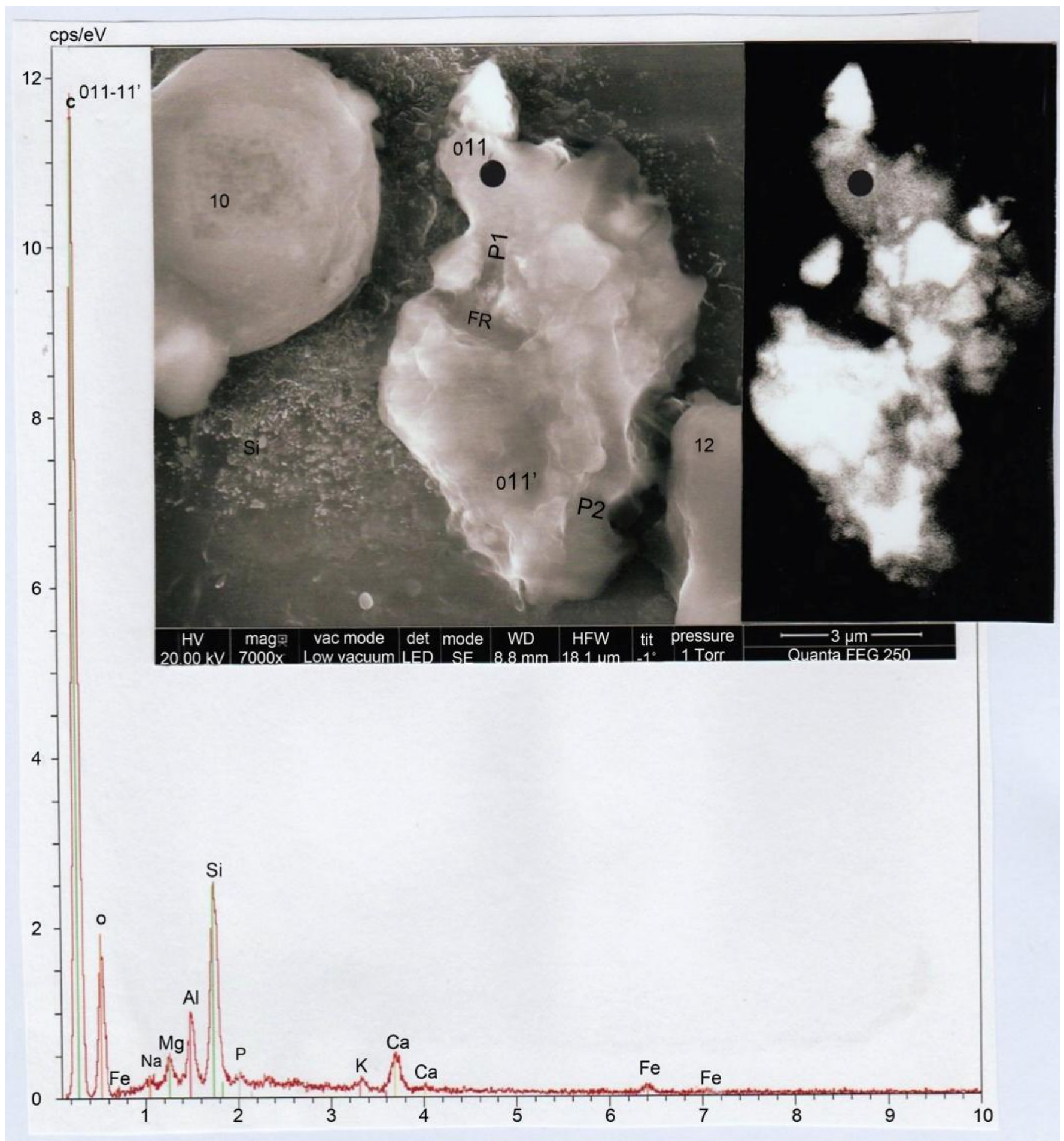

Figure 15. Above: SEM photographs $(7000 \times)$ of the o11-11' particles (left photography, in LFD; right photography, in CBS); FR: fracture zone, P1 and P2: pores 1 and 2. Adjacent particles o10 (an hematite) and o12 (a plastic PVC). Below: o11 = 11' spectrum, taken at the black points indicated on the photographs.

On the whole, presence of these only ten exogenous particles of red-yellow colour cannot explain all of the observed reddish colouration of the blood stain. To explain 


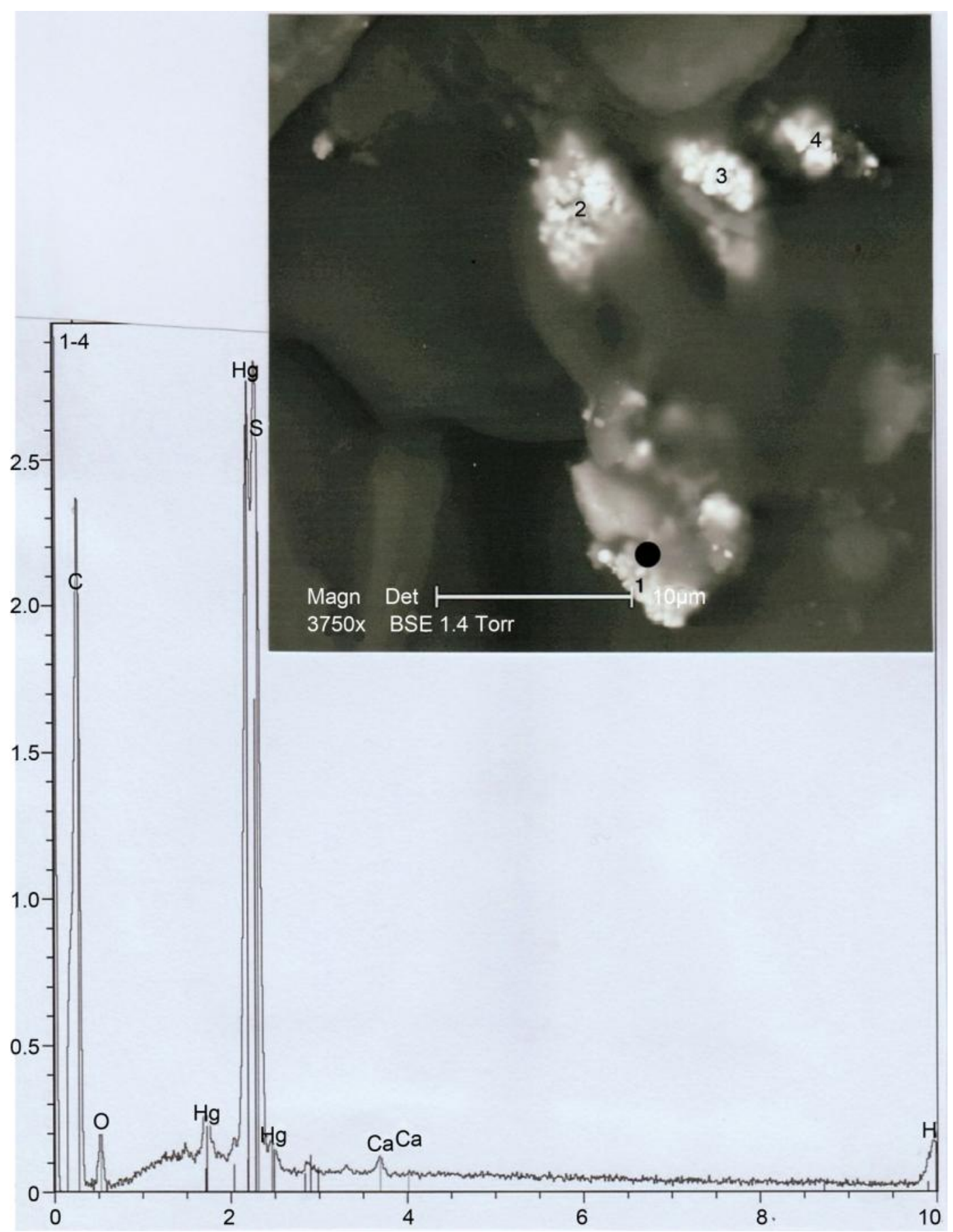

Figure 16. Vermilion particles on the Prüm Sandal. Above: SEM (3750×) photography of four $(1-4)$ vermilion particles. Below: particle 1 spectrum, at the black point indicated.

this discordance, we move now to the characterisation of ochre particles that are numerous in some areas of the triangle.

\section{References}

[1] Marion, A. and Lucotte, G. (2006) Le linceul de Turin et la Tunique d'Argenteuil. Presses 
de la Renaissance, Paris.

[2] Heller, J.H. and Adler, A.D. (1980) Blood on the Shroud of Turin. Applied Optics, 19, 27422744. http://dx.doi.org/10.1364/AO.19.002742

[3] Heller, J.H. and Adler, A.D. (1981) A Chemical Investigation of the Shroud of Turin. Canadian Society of Forensic Science Journal, 14, 81-103. http://dx.doi.org/10.1080/00085030.1981.10756882

[4] McCrone, W.C. and Skirius, C. (1980) Light Microscopical Studies of the Turin Shroud. Microscope, 28, 105-112.

[5] Van der Hoeven, A.A.M. (2015) Cold Acid Post-Mortem Blood Most Probably Formed Pinkish-Red Heme-Madder Lake on Matter-Dyed Shroud of Turin. Open Journal of Applied Sciences, 5, 705-746. http://dx.doi.org/10.4236/ojapps.2015.511070

[6] Lucotte, G. (2015) Red Blood Cells on the Turin Shroud. Jacobs Journal of Hematology, 1, 1-24.

[7] Lucotte, G. (2012) Optical and Chemical Characteristics of the Mineral Particles Found on the Face of the Turin Shroud. Scientific Research and Essays, 7, 2545-2553.

[8] Lucotte, G. (2015) Exploration of the Face of the Turin Shroud. Linen Fibres Studied by SEM Analysis. International Journal of the Latest Research in Science and Technology, 4, 78-83.

[9] Lucotte, G. (2015) Exploration of the Face of the Turin Shroud. Pollens Studied by SEM Analysis. Archaeological Discovery, 3, 158-178. http://dx.doi.org/10.4236/ad.2015.34014

[10] Cornell, R.M. and Schwertmann, U. (1996) The Iron Oxides. VCH Verlagsgellschaft, Weinheim.

[11] Pomiès, M.P., Menu, M. and Vignaud, C. (1999) Red Paleolithic Pigments: Natural Hematite or Heated Goethite? Archaeometry, 41, 275-285.

http://dx.doi.org/10.1111/j.1475-4754.1999.tb00983.x

[12] Pomiès, M.P., Menu, M. and Vignaud, C. (1999) TEM Observations of Goethite Dehydratation: Application to Archaeological Samples. Journal of the European Ceramic Society, 19, 1605-1614. http://dx.doi.org/10.1016/S0955-2219(98)00254-4

[13] Gialanella, S., Belli, R., Dalmeri, G., Lonardelli, J., Mattarelli, M., Montagna, M. and Toniutti, L. (2011) Artificial and Natural Origin of the Hematite-Based Red Pigments in Archaeological Contexts: The Case of Riparo Dalmeri (Trento, Italy). Archaeometry, 53, 950 962. http://dx.doi.org/10.1111/j.1475-4754.2011.00594.x

[14] Buisson, D., Menu, M., Pinçon, G. and Walter, Ph. (1989) Les objects colorés du Paléolithique supérieur: cas de la grotte de la Vache (Ariège). Bulletin de la Socitété Préhistorique Française, 86, 183-192. http://dx.doi.org/10.3406/bspf.1989.9384

[15] Delamare, F. and Guineau, B. (1999) Les matériaux de la couleur. Gallimard, Paris. 


\section{Appendix}

\section{Appendix 1: Hematite}

Hematite is a mineral form of iron oxide (III), of formula $\mathrm{Fe}_{2} \mathrm{O}_{3}$. Hematite is one of the most common minerals (and responsible for the red colour of many minerals). The colour can be black, grey or silver grey, brown to reddish brown, or red. The crystal system is hexagonal.

Figure S1 shows iron hematite inclusions in our hematite specimen of reference (GL Hem.1).

\section{Appendix 2: Biotite}

Biotite is a phyllosilicate of formula $\mathrm{K}\left(\mathrm{Mg}, \mathrm{Fe}_{3}{ }^{2+}\right)\left(\mathrm{Al}, \mathrm{Fe}^{3+}\right) \mathrm{Si}_{3} \mathrm{O}_{10}(\mathrm{OH}, \mathrm{F})_{2}$; it is a very

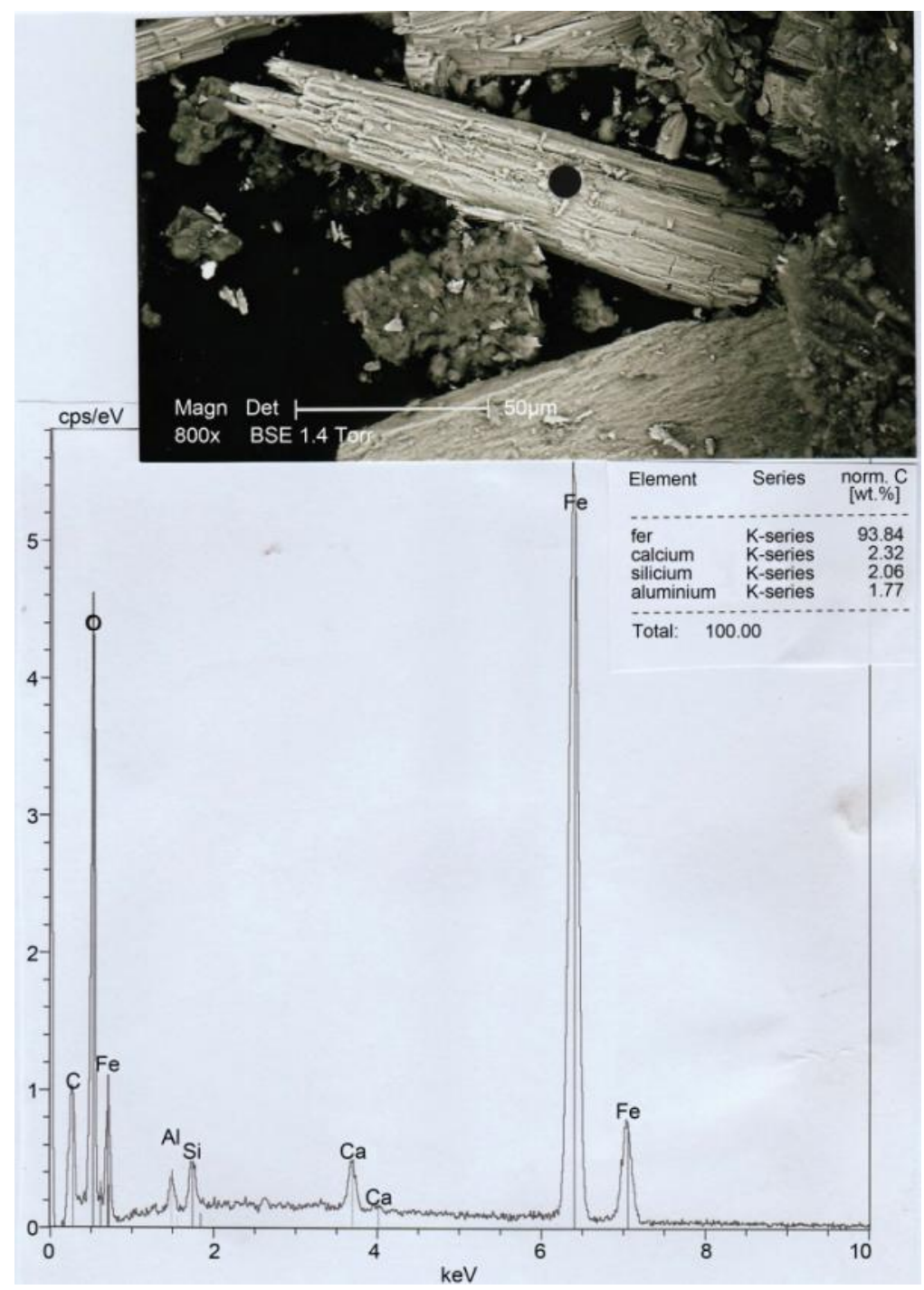

Figure S1. An iron inclusion in a hematite mineral of reference. Above: SEM (800×) photography of iron oxide inclusions in the hematite mineral. Below: iron oxide spectrum (at the black point) in the fibrous iron inclusion (the table indicates iron percentage). 
common form of mica. Biotite is an essential constituent of magmatic and metamorphic rocks (granites, gneiss, micashists...). Biotite is until now a traditional name commonly used, but in 1998 this term was removed as an individual mineral species and instead declared as a group name for other individual members: phlogopite, siderophyllite, annite and eastonite.

The biotite crystal system is monoclinic; cleavage is perfect, blades being thick, flexible and elastic. Crystals are in thick flakes, micaous masses and groupings, and in tabular foliated, flaky and scaly forms. Crystals may be elongated with one dimension flat, or stubby triangular or hexagonally shaped crystals. The two main forms are crystals composed of dense parallel plates, or as rounded nodules of dense crystals.

Biotite color is black, dark brown or reddish black. Phlogopite and eastonite can be in lighter colours.

Figure S2 shows biotite leafs in our biotite specimen of reference (GL Biot.1).

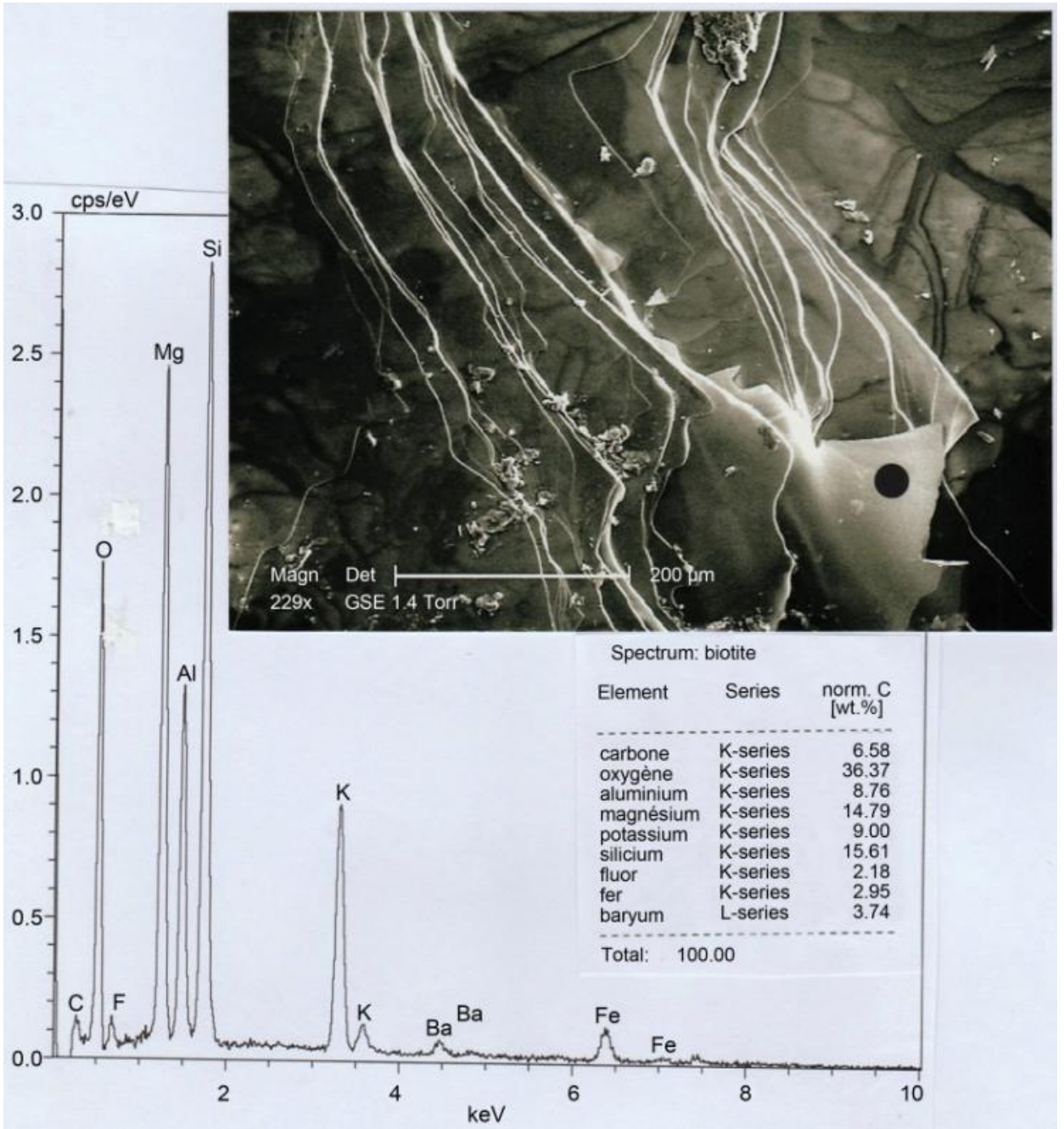

Figure S2. A biotite mineral of reference. Above: SEM (229x) photography of some portion of the biotite mineral. Below: biotite spectrum (at the black point) of this portion (the table indicates elemental percentages). 


\section{Appendix 3: Goethite}

Goethite (characteristic formula: $\alpha$ - $\mathrm{FeO}(\mathrm{OH})$ ) is an iron hydroxide mineral found in soil and other (generally) low-temperature environments. It is usually a fine powder of yellow colour minerals. The mineral is always some general form of silicate; the crystal is orthorhombic, but crystal habits may be radial, acicular, mammillary, botroydal, stalactic, or even massive (under the form of incrustations on other mineral substrates). Goethite has been known since ancient times for its use as pigment (under the vague term of "yellow ochre").

Figure S3 shows the goethite particle 17, located in the $\mathrm{L}$ area. There are at least two well characterized goethite particles (a22 and b70) on the triangle surface.

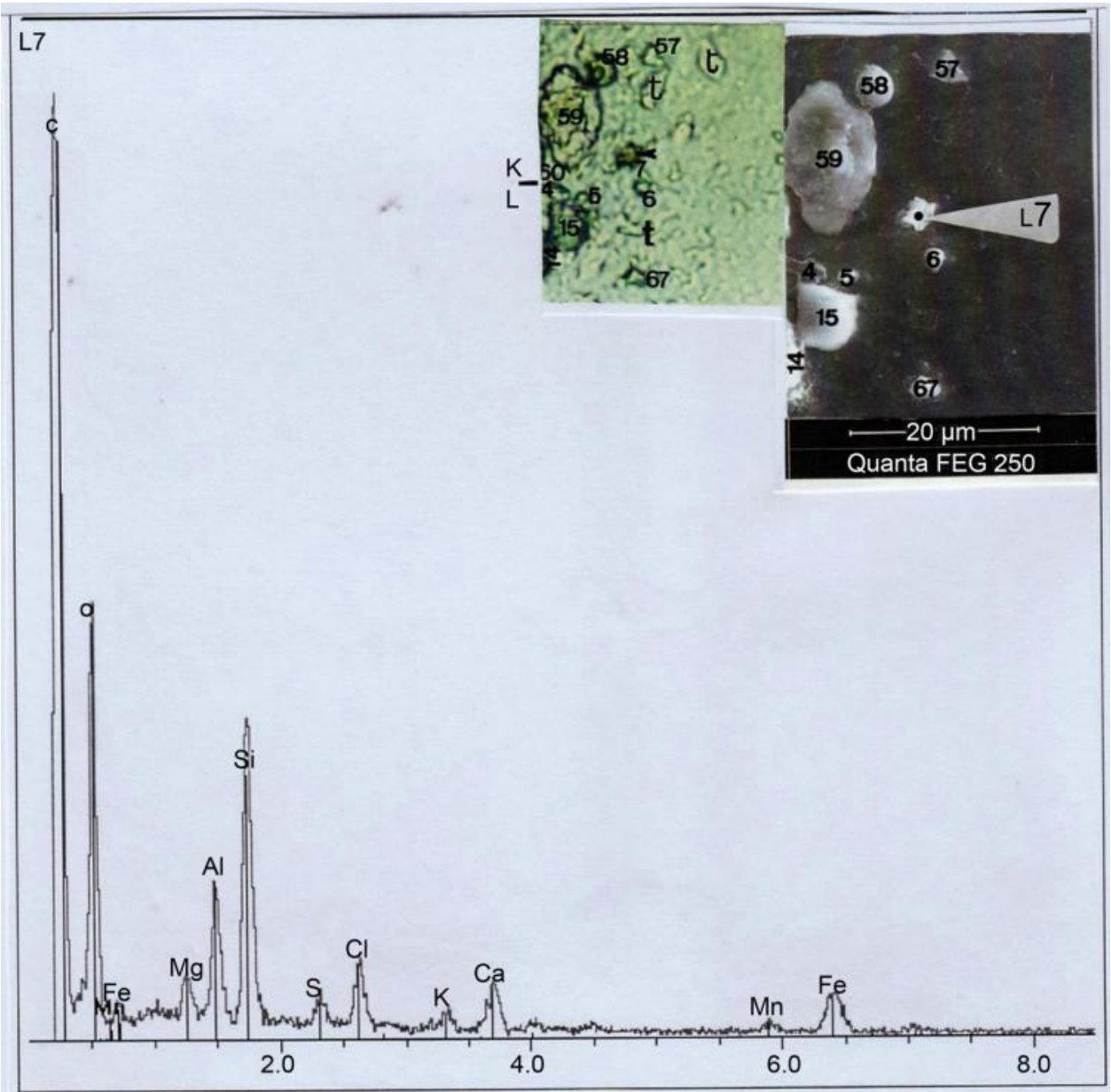

Figure S3. The goethite particle 17. Above: $(1000 \times)$ photography of the 17 particle; at the left: an optical microscopy photography $(800 \times)$ at the limit between the $\mathrm{K}$ and $\mathrm{L}$ areas, where the 17 particle is indicated by an arrow point (t: holes; $\mathrm{k} 57$ : calcite, $\mathrm{k} 58$ : a spore; $\mathrm{k} 59$ : a K-aluminosilicate; 14: an organic particle; 15: calcite; 16, 115 and 167: calcium carbonates). Below: the 17 spectrum, at the point indicated as a little black point (note that there is manganese, this indicating the mineral nature of the iron). 
Submit or recommend next manuscript to SCIRP and we will provide best service for you:

Accepting pre-submission inquiries through Email, Facebook, LinkedIn, Twitter, etc. A wide selection of journals (inclusive of 9 subjects, more than 200 journals)

Providing 24-hour high-quality service

User-friendly online submission system

Fair and swift peer-review system

Efficient typesetting and proofreading procedure

Display of the result of downloads and visits, as well as the number of cited articles

Maximum dissemination of your research work

Submit your manuscript at: http://papersubmission.scirp.org/

Or contact ojapps@scirp.org 